\title{
IMPLEMENTATION OF HUMAN RESOURCES COMPETENCY IN NURSING SERVICES FIELD IN INDUSTRIAL REVOLUTION 4.0 ERA: A STUDY AT REGIONAL GENERAL HOSPITAL OF KLUNGKUNG
}

\author{
Sutiari Ni Wayan*, Suryanata I Gusti Ngurah Putra \\ Undiknas Graduate School, Bali, Indonesia \\ `E-mail: nisutiari@gmail.com
}

\begin{abstract}
The purpose of the study is to obtain an overview of the implementation of human resource competencies in the field of nursing services in the era of the industrial revolution 4.0 at Regional General Hospital of Klungkung. This research is a qualitative descriptive study with inductive approach using primary data and secondary data obtained using interviews and observation methods from informants and documents from Regional General Hospital of Klungkung. The data was processed qualitatively and tested for validity using the triangulation method. The results of the study found that nurses had performed their competencies well. The hospital has also implemented nursing competencies in accordance with the era of the industrial revolution 4.0 such as the use of existing application systems in hospitals. In addition, the hospital also held education and training and dissemination of training results in an effort to develop human resources in improving service quality in the era of the industrial revolution 4.0 .
\end{abstract}

\section{KEY WORDS}

Competency, human resources, nursing, industrial revolution 4.0.

The Industrial Revolution 4.0 is an era marked by the development of the Internet of Things (IoT). IoT is not only potential in affecting the way we live but the way we work as well (Savitri, 2019). Many things that were not thought of before, suddenly appeared and became a big innovation, and opened up a large business area. In facing the Industrial Revolution 4.0 it is needed to have various types of skills, namely: information, media and technology skills, learning and innovation skills, life and learning skills, and effective communication skills (Agustina, 2019).

The development of industry 4.0 requires a change in service paradigm including in nursing services and care. The role of information systems in the 4.0 era has became very important in assisting nurses and its management in determining the form of nursing information systems that are integrated with hospital information systems. It is necessary to strengthen the management and also the ongoing supervision process so that the implementation of information systems in the 4.0 era can provide great benefits for the improvement of professional nursing care (Hariyati in Niken, 2019)

The Regional General Hospital of Klungkung Regency is a hospital owned by the Regional Government of Klungkung Regency which vision is being the best and superior choice hospital in emergency services in Eastern Bali. In accordance with this vision, Klungkung Regional Hospital has to maintain and improve not only the facilities and infrastructure but also quality of the competence of its human resources so that the quality of its services is in accordance with established standards.

\section{LITERATURE REVIEW}

Human resources are the most important element in an organization compared to other elements such as capital, technology and money because humans themselves control other elements (Harianja, 2002; Nawawi, 2003; Priansa, 2018). Human resources have a very important role and should be developed in a company (Hasibuan, 2000). According to Sunyoto (2012), HR development has a wider scope in efforts to improve and enhance 
knowledge, abilities, and attitudes through training. Workforce training for an organization is an important activity where it can affect the level of work productivity and achievement for the workforce itself and for the progress of the organization. Training is also needed if there are special problems that hamper organizational productivity such as labor movement, work accidents, excessive fall in work output and others.

HR development is closely related to the competence of HR itself. Competence is the ability to carry out or do a job or task based on the skills and knowledge and is supported by the attitude required by the job (Mathis \& Jackson, 2001; Armstrong, 2009; Wibowo, 2016; Sudarmanto, 2009). Competence is a reference and basis for company management in managing human capital, starting from the recruitment and selection process, performance management, training and management development for potential employees, retention and remuneration. Competence effectively translates the organization's vision and strategic goals into observable behavior or actions that must be performed by employees (Marwansyah, 2019). Competence can be formed by 5 characteristics namely motive, traits, self-concept, knowledge, and skills (Palan, 2007: 84). Kunandar (2007) mentions competencies can be divided into 5 (five) parts namely: intellectual competence, physical competence, personal competence, social competence, and spiritual competence.

In the field of nursing, competency standards reflect the competencies that nurses must possess to provide professional nursing care. The Indonesian Nurses Competency Areas are grouped in 3 Competency Areas namely Professional Practice, ethical, legal and cultural sensitive; provision of care and management of nursing care; and the development of personal and professional qualities.

Head of the State Civil Service Agency (BKN), Bima Haria Wibisana stated that the current environmental change was caused by one of them by the industrial revolution 4.0 (digital technology system). The 4.0 industrial revolution can affect work, workers and the workplace. Bima said that the competence of civil servants needed now is not only technical, but also non-technical skills. Every civil servant needs some non-technical skills to face the challenges of change. These skills include the ability to solve complex problems, critical thinking, creativity, human management, the ability to coordinate, as well as having emotional intelligence, skills in terms of assessing and making decisions, service-oriented, negotiation skill, and cognitive flexibility. In terms of gaining competence and developing it, a civil servant can also obtain it by other methods, namely through education and training.

According to Smith (2000: 2), training is a planned process for changing attitudes / behaviors, knowledge and skills through learning experiences to achieve effective performance in an activity or a number of activities. Employee education and training contribute to increasing productivity, effectiveness and organizational efficiency. Rivai (2009: 213) states that training is usually focused on efforts to improve employee performance through providing learning of special skills or helping them to correct weaknesses in their performance, in the training given instructions to develop skills that can be directly used on the job. Through training, all efforts are made to improve employee performance in the jobs they currently occupy.

\section{METHODS OF RESEARCH}

The research is a qualitative descriptive study with an inductive approach carried out at the Regional General Hospital of Klungkung in 2019. This study used primary data obtained by conducting focused group discussion and in-depth interviews with informants and secondary data by doing the observations directly by visiting treatment room or indirectly by requesting the required documents. In collecting research results, the informant is the person who masters the information and data that the writer needs (Sugiono, 2014), namely: Director of Regional General Hospital of Klungkung, Head of Nursing Services, Nurses / midwives who provide direct services to patients in inpatients, patients / families patients as recipients of nursing services. The research data were then analyzed qualitatively using an interactive model. The validity test is carried out using the Triangulation method, which is 
data analysis that synthesizes data from various sources in various ways, and at various times to test the validity of research data.

\section{RESULTS AND DISCUSSION}

Hospitals are an integral part of the overall health care system developed through a health development plan. Hospital management is also complex with scientific disciplines, including: medical, nursing, engineering, economics, law and public relations disciplines. The quality of nursing services will determine the achievement of increasing the degree of good health in hospital services. Improving the quality of nursing services in the industrial revolution 4.0 era does not only prioritizes technological development, but also must prioritize bio-psycho-sociocultural health in nursing. In addition, improving the quality of this service must also be supported by a synergy between evidence based in the clinic and also the development of science and technology in nursing education. To produce quality services in accordance with patient expectations, HR competencies, especially HR that are directly related to the care process are very important.

Implementation of HR competencies in the field of nursing services in the era of the industrial revolution 4.0 in Regional General Hospital of Klungkung, based on the results of interviews with the Director of Regional General Hospital of Klungkung, that as professional nurses the competencies possessed by professional nurses are based on competency standards set by the profession. According to Indonesian law, the PPN, 2005 nurse competency standards reflect the competencies that must be possessed by Nurses to provide professional nursing care. Indonesian Nurse Competencies. The Nurse Competency Framework is grouped into three (3) Competency Areas as follows;

1. Professional practice, ethical, legal and culturally sensitive

2. Provision of care and management of nursing care.

3. Development of personal and professional quality

The results of the interview also found that the Regional General Hospital of Klungkung applied nursing competencies in clinical practice so that the nurses' competencies in nursing care services were in accordance with established standards. This is based as Uliya in Niken (2019), who stated that as individuals who live in this era, they have to compensate these developments with being "wise", using soft skills or a good attitude. Nurses must adapt to the optimal attitude with maximum self-management and not abandon what is the basic attitude of a nurse, caring. Caring which is the body of knowledge must always be attached to nurses in any era. In connection with the Industrial Revolution Era 4.0, the Director of the Regional General Hospital of Klungkung also said that in the future the serious challenge of hospitals is how nursing competence follows this digital role. Nurses not only master nursing care manually, but nurses must also be equipped with digital nursing care competencies. In the future the direction is not only computerized but the direction itself is based on Android OS. These results are in accordance with the literature by Schwab (2019) which states that the health industry is faced with the challenge of combining physical, biological and digital technological advances simultaneously, as the development of various diagnostic and therapeutic approaches that have just emerged together with the drive to digitize the patient's track record. Not only that, it is also open to the possibility to capitalize on the abundance of information that can be collected from the devices that are worn as well as the technology embedded.

Nursing care at Regional General Hospital of Klungkung is still carried out in conventional care, which is still in direct contact with patients with nurses that we prepare to meet the needs of patients, both bio-psycho-social-spiritual conducted by nursing staff. It's just that administration and evidence of nursing services need to be documented digitally so that it is not easily lost and becomes easier and more efficient. Therefore all nurses are expected to master computers or digitalization. The nurse accompanies the patient for 24 hours and provides direct nursing care services to patients.

This Industrial Revolution Era 4.0, with the use of sophisticated medical devices, nurses can focus more on monitoring the condition of patients through a monitor, besides 
there are also some actions that are still done manually, but more care is done through direct contact. The provision of nursing services to patients is comprehensive, both direct nursing care and indirect care. Direct nursing services namely by contact / direct contact with patients, for example: when examining 4 cardinal symptoms, bathing the patient, etc., the existence of eye contact and staff touch to the patient. Indirect services that are outside the service directly to patients, but are still related to improving the quality of services, such as: writing medical records of patients, the use of existing application systems in hospitals and inputting documents through sismadak (document management system).

There are innovations to improve service quality, namely Case Reflection Discussion (DRK), a learning method in the form of discussion groups to share clinical experiences about disease cases. Reporting from the implementation of this DRK is based on WhatsApp, so reports on the results of case discussions can be viewed through each employee's android mobile phone. Other innovations in the form of SILAPISSUPER (nursing supervision report system) applications are made for the implementation of nursing supervision. With this application, it is expected that problems that occur in inpatient services can be solved. In addition, the Regional General Hospital of Klungkung also budgeted the development of digitalization in the form of "E" in the Regional General Hospital of Klungkung as a priority, to facilitate human resources, so that officers could focus more on providing services to patients. Service monitoring system with existing devices and also developing service systems based on digital or android. One of them is a medical E-Record in which there will be services of health workers in it. Other developments that will be carried out are Medical EServices, Nursing Services, Administration Services. The results of the research revealed that the quality and completeness of documentation improved after using a computer-based system, as well as an increase in legality, relevance and increased decision-making ability. After using the computer there was also an increase in nurse satisfaction because it was easier and more time efficient (Hariyati in Niken, 2019).

With the development of the digital-based program, the readiness of nursing human resources in using the application is also needed. For this reason, education and training are needed to be able to take advantage of this system. Specifically for the Medical E-Record, of course various types of health workers including nurses will be trained and assisted until they can do it ready, the third party invited to work together has prepared a system that requires training and mentoring for the system well targeted in 2020. While for applications prepared by hospital IT HR, specifically for the field of nursing such as SILAPISSUPER, socialization and assistance have been held by hospital HR IT. This is consistent with research that says innovation in companies depends on the ability of people and companies. The right management approach can play an important role in developing dynamic capabilities, as well as an effective climate of learning and innovation (Saqib, 2016).

The development of competency enhancement, both for digital / android based development and for improvement according to competency standards, is carried out through training, in-house / inservice training, workshops and dissemination of training results. Continuing education, where the education of nurses used to be only graduated from the School of Health Nurses (SPK), was upgraded to D3 level, Nurses who had D3 education were upgraded again to the S1 Nurses level. In addition to increasing knowledge and skills, there is also training or seminars. All nurses are required to attend the education for more than 20 hours a year. Nurses who attend training are required to socialize it to all nurses who do not receive training. When compared with the results of research at Surabaya Haji Hospital, that the development of HR competencies is basically well-planned. This is evident from the scale of priorities applied in the development of HR competencies, such as which installations is the focus of developing HR competencies and what competencies must be developed in each of these installations due to the different characteristics of each other. However, if judging further, the development of HR competencies in Surabaya Haji Hospital cannot be said to be evenly distributed, because it still prioritizes employees who have PNS status rather than honorary. But nursing human resources at Regional General Hospital of Klungkung get the same opportunity in understanding. 


\section{CONCLUSION}

The results showed that the industrial revolution 4.0 not only promoted technological development, but also improved the quality of care services to meet the bio-psycho-sociocultural needs of patients in providing nursing care. What has been done to support the improvement of nursing care quality in the industrial revolution era 4.0 is the writing of medical record of patients, the use of existing application systems in hospitals and the input of documents through SISMADAK, the use of existing applications, the reporting of DRK results through WhatsApp applications and applications for the nursing supervision report. In addition, there are also other applications that are being developed in Regional General Hospital of Klungkung, such as: E-Medical Services, E-Nursing Services, and EAdministrative Services. In addition, the hospital also provides higher education, training, inhouse / in-service training, workshops and information dissemination on training results in an effort to develop human resources in improving service quality in the industrial revolution era 4.0.The direct impact of the implementation of nurse competence while providing nursing care to patients and caregivers of patients in Regional General Hospital of Klungkung, was conveyed that all nurses worked very well, all patients were treated equally and were not discriminated by nurses. This is due to good communication between nurses and patients and their families.

Based on the results of the study, we suggest that the implementation needs to be monitored and reviewed periodically to evaluate the implemented competencies.

\section{REFERENCES}

1. Adikoesoemo (2017). Manajemen Rumah Sakit, Jakarta: Pustaka Sinar Harapan.

2. Agustina (2019). Kewirausahaan di Era Revolusi Industri 4.0, Mitra Wacana Madia.

3. Armstrong, Michael (2004). Performance Management (Terjemahan Toni Setiawan), Yogyakarta, Tugu Publisher.

4. Bungin, B (2017). Metodologi Penelitian Kwalitatif, Aktualisasi Metodologis ke Arah Varian Kontemporer: Depok: PT Raja Grafindo Persada.

5. Carillo et al (2004). Knowledge Management system performance measure index. Pergamon Press, Inc. Tarrytown, NY, USA.

6. Ferdinand, A. (2014). Metode Penelitian Manajemen: Undip Press, edisi 5.

7. Hariandja, Marihot T.E (2002). Manajemen Sumber Daya Manusia. Jakarta: Grasindo.

8. Hasibuan, Malayu S.P (2001). Manajemen Sumber Daya Manusia. Jakarta: PT. Bumi Aksara.

9. Hasibuan, Sayuti (2000). Manajemen Sumber Daya Manusia: pendekatan non sekuler. Muhammadiyah University Press and Magister Manager UMS, Surakarta.

10. Hoetomo M.A (2005). Kamus Lengkap Bahasa Indonesia. Surabaya: Mitra Pelajar.

11. Hutapea, Parulian and Nurianna Thoha (2008). Kompetensi Plus. Jakarta, PT Gramedia Pustaka Utama.

12. Indonesia, P.P.N (2005). Standar kompetensi perawat Indonesia. Bidang Organisasi PPPPNI: Jakarta.

13. Indrawati (2018). Metode Penelitian Kwalitatif Manajemen and Bisnis Konvergensi Teknologi Informasi and Komunikasi, Bandung: PT Refika Aditama.

14. Jonirasmanto (2009). Mutu Pelayanan Kesehatan: Ambivalensi Antara Kewajiban and Keinginan (Antara Penyelenggara and Pemilik). Hal Mutu Pelayanan Rumah Sakit/05.11.

15. Karassavidou, E., Glaveli, and N., Papadopoulos, C. T (2009). Quality In Nhs Hospitals: No One Knows Better Than Patients. Measuring Business Excellence J, 13 (1): 34-46.

16. Keputusan Kepala Badan Kepegawaian Negara Nomor 46a Tahun 2003 Tentang Pedoman Penyusunan Standar Kompetensi Jabatan Struktural Pegawai Negeri Sipil Kepala Badan Kepegawaian Negara.

17. Kessler, R (2008). Competency Based Review. Career Press.

18. Kunandar (2007). Guru Profesional Implementasi Kurikulum Tingkat Satuan Pendidikan (KTSP) and Persiapan Menghadapi Sertifikasi Guru.Jakarta: Raja Grafindo: Persada. 
19. Marwansyah (2019) Manajemen Sumber Daya Manusia, Bandung: Alfabeta.

20. Mathis, R. L., and J.H. Jackson (2001). Manajemen Sumber Daya Manusia, buku 1 and buku 2, Terjemahan. Jakarta: Salemba Empat.

21. Miles, M.B. (1994). Qualitative data analysis (2nd ed.). Thousand Oaks, CA: Sage.

22. Moleong \& Lexy J (2001). Metodelogi Penelitian Kualitatif, Penerbit Remaja Rosdakarya, Bandung.

23. Nawawi, Hadari (2003). Kepemimpinan Mengefektifkan Organisasi. Yogyakarta: Gajah Mada University Press.

24. Niken, S. D (2019). Prosiding Seminar Nasional Keperawatan "Kolaborasi Pendidikan and Pelayanan Keperawatan dalam Era Revolusi Industri 4.0".

25. Notoatmodjo, S (2003). Metodologi Penelitian Kesehatan, Jakarta: Rineka Cipta.

26. Peraturan Menteri Kesehatan RI nomer 56 Tahun 2014 tentang Klasifikasi and Perizinan Rumah Sakit.

27. Peraturan Pemerintah Nomor 101, Tentang Pendidikan and Pelatihan Jabatan Pegawai Negeri Sipil.

28. Poerwadarminta, W.J.S (1990). Kamus Besar Bahasa Indonesia.Jakarta: Balai Pustaka.

29. Priansa, D.J (2018) Perencanaan and Pengembangan Sumber Daya Manusia, Bandung.

30. Ratnamiasih, I., Govindaraju, R., Prihartono, B. and Sudirman, I., 2012. Kompetensi SDM and Kualitas Pelayanan Rumah Sakit. Budhi, 11(1).

31. Rohida. L (2018). Pengaruh Era Revolusi 4.0 Terhadap Kompetensi Sumber Daya Manusia, Jurnal Manajemen Bisnis Indonesia, vol.6, nomor 1.

32. Savitri, A (2019). Revolusi Industri 4.0 Mengubah Tantangan Menjadi Peluang di Era Disrupsi 4.0, Yogyakarta: Ganesha.

33. Schuler, Randall S. (1992). Human Resource Management in Australia. Artannon-NSW: Harper Educational Publishers.

34. Schwab, K (2019). Revolusi Industri Keempat, Jakarta: PT Gramedia.

35. Sedarmayanti (2016). Manajemen Sumber Daya Manusia Reformasi Birokrasi and Manajemen Pegawai Negeri Sipil: Bandung: PT Refika Aditama.

36. Sedarmayanti (2009). Sumber Daya Manusia and Produktivitas Kerja. Bandung: CV Mandar Maju.

37. Sedarmayanti (2016). Manajemen SDM, Reformasi Birokrasi and Manajemen Pegawai Negeri Sipil, Bandung: RefikaAditama.

38. Shamim, S., Cang, S., Yu, H. and Li, Y., 2016, July. Management approaches for Industry 4.0: A human resource management perspective. In 2016 IEEE Congress on Evolutionary Computation (CEC) (pp. 5309-5316). IEEE.

39. Smith, Andrew. 2000. Training and Development In Australia. Second Edition, Reed International Books Australia Pty Buuterworths. Australia.

40. Spencer (2001). The Compentency Handbook, volume 1\&2 Boston: linkage.

41. Suaedi, F., 2017. Pengembangan Kompetensi Sumber Daya Manusia dalam Rangka Meningkatkan Pelayanan di Rumah Sakit Haji Surabaya. Al Tijarah, 3(1), pp.79-102.

42. Sudarmanto (2009). Kinerja and Pengembangan Kompetensi SDM, Teori, Dimensi Pengukuran and Implementasi dalam Organisasi, Yogyakarta: Pustaka Pelajar.

43. Sugiono (2014). Metode Penelitian Bisnis, Bandung: Penerbit Alfa Beta.

44. Sugiyono (2018). Metode Penelitian Kualitatif, Bandung: Alfabeta, edisi 3.

45. Sugiyono (2018). Metode Penelitian Manajemen, Bandung: Alfabeta.

46. Sunyoto, Danang (2012). Manajemen Sumber Daya Manusia. Yogyakarta: CAPS (Center for Academic Publishing Service).

47. WHO (2003), Pelatihan Keterampinan Manajemen SPMK. Jakarta.

48. Wibowo (2016). Manajemen Kinerja, Jakarta: Raja Grafindo Persada.

49. Wickramasinghe, V, and De Zoyza, N (2007). A Comparative Analysis Of Managerial Competency Needs Across Areas Of Functional Specialization. Department of Management of Technology, Faculty of Engineering, University of Moratuwa, Moratuwa, Sri Lanka.

50. Wina Sanjaya (2005). Pembelajaran dalam Implementasi Kurikulum Berbasis Kompetensi. Jakarta: Kencana Prenada Media Grup. 